\title{
INTERNET UTILIZATION PATTERN AMONG AGRICULTURAL STUDENTS
}

\author{
NAVEEN KUMAR GAUTAM ${ }^{1}$, SHARAD YADAV $^{2} \&$ V. K. SINGH ${ }^{3}$ \\ ${ }^{1,2}$ Research Scholar, Department of Agricultural Extension in Chandra Shekhar Azad \\ University of Agriculture \& Technology, Kanpur, India \\ ${ }^{3}$ Head of the Department of Agricultural Extension in Chandra Shekhar \\ Azad University of Agriculture \& Technology, Kanpur, India
}

\begin{abstract}
An exploratory study on internet utilization pattern among agriculture student is conducted in the Chandra Shekhar Azad University of Agriculture and Technology Kanpur. Examine study, Information sharing and entertainment related factors that may affect the adoption of an innovation or product such as personal computer laptop mobile etc. For the study, a scale was developed by Department of Agricultural extension to measure internet utilization pattern of 120 students and students were approached personally by the investigator for the collection of relevant data the result of study suggests that most of the respondents have the positive effect on their overall performance due to internet use.

KEYWORDS: VSNL, Google-Scholar, Shodh-Ganga \& Internet
\end{abstract}

Received: Feb 01, 2018; Accepted: Feb 21, 2018; Published: Mar 01, 2018; Paper Id.: IJESRAPR20182

\section{INTRODUCTION}

After the third technological revolution (1980), the Internet has become the most accessible means of exchange of information Just as the Green Revolution had come to increase the production of crops, white revolution was expanded to increase the milk production area, the same way the Internet is being used in this century, it seems the Internet revolution is going on at the present time. In India, the Internet services were officially made available to the public from $15^{\text {th }}$ August 1995 onwards through Videsh Sanchar Nigam Limited (VSNL). Today there are many service providers offering Internet services. With the rising demand of trained manpower for agricultural development activities, Indian Council of Agricultural Research (ICAR) took over leadership and encouraged the setting up of exclusive State Agricultural Universities (SAUs) with mandates to provide research, education, and extension of the lines of Land Grant System of the USA. In India nowadays total 38 SAUs and 5 deemed agricultural universities are doing an excellent job to create bright human resources for agricultural education, research and extension activities.

\section{METHODOLOGY}

To measure the pattern Internet utilization of the C. S. A. U. A. \& T. Students, a total of 6 indicators was used viz. 1) Experience of Internet use; 2) Places \& preferable time of access to Internet; 3) Expenditure spent on Internet use; 4) Frequency of Internet use; 5) Purpose of Internet use; 6) Exposure of informative sites; For gathering information from students, a questionnaire was made with the help of extension experts \& interview method was preferred for it. 


\section{RESULT AND DISCUSSIONS}

\section{Experience of Internet Use}

Experience of internet users was measured in terms of a total number of year or years of the respondent's exposure to the internet. The data in table no.1 explain that the majority of the respondents $(76.66 \%)$ were using the internet for above three years, followed by $15.00 \%$ using the internet for up to two-three year and $8.33 \%$ of the respondents were using the internet for the last one year only.

Table 1: Respondents According to Their Experience of Internet Use

\begin{tabular}{|c|c|c|c|}
\hline & Category & Frequency & Percentage \\
\hline 1. & Up to one year & 10 & 8.33 \\
\hline 2. & Up to two-three year & 18 & 15.00 \\
\hline 3 & Above three years & 92 & 76.66 \\
\hline & Total & $\mathbf{1 2 0}$ & $\mathbf{1 0 0}$ \\
\hline
\end{tabular}

\section{Places \& Preferable Time of Access to Internet}

The data collected from respondents in the regard of place \& timings of access to the internet have been presented in the table no.2. The table showed that the majority (56.66\%) accessed the internet at the hostel or their own place \& most of them preferred the night time, followed by $47.50 \%$ having access at concerned department \& most of them preferred noon time, whereas $40.00 \%$ of the respondents using the internet at library \& mostly they preferred the noon time and only $19.16 \%$ of respondents accessed the internet at cybercafé.

Table 2: Respondents According to Their Places of Access and Time Preferences

\begin{tabular}{|c|c|c|c|c|c|c|c|c|c|c|c|}
\hline \multirow{3}{*}{ S. $\mathbf{N}$} & \multirow{3}{*}{ Category } & \multirow{3}{*}{$\mathbf{F}$} & \multirow{3}{*}{$\%$} & \multicolumn{8}{|c|}{ Timing Preferences } \\
\hline & & & & \multicolumn{2}{|c|}{ Morning } & \multicolumn{2}{|c|}{ Noon } & \multicolumn{2}{|c|}{ Evening } & \multicolumn{2}{|c|}{ Night } \\
\hline & & & & $\mathbf{F}$ & $\%$ & $\mathbf{F}$ & $\%$ & $\mathbf{F}$ & $\%$ & $\mathbf{F}$ & $\%$ \\
\hline 1. & Hostel & 68 & 56.66 & 18 & 26.47 & 11 & 16.17 & 12 & 17.64 & 27 & 39.70 \\
\hline 2. & Department & 57 & 47.50 & 22 & 38.60 & 30 & 52.63 & 5 & 8.77 & 0 & 00 \\
\hline 3. & Library & 48 & 40.00 & 9 & 18.75 & 17 & 35.41 & 12 & 30.00 & 0 & 00 \\
\hline 4 & Cyber café & 23 & 19.16 & 3 & 13.04 & 9 & 39.13 & 11 & 47.80 & 0 & 00 \\
\hline
\end{tabular}

*Multiple responses were allowed

\section{Expenditure Spent on Internet Use}

Expenditure spent on internet use was measured in terms of rupees spent per month for internet use. The data in table 3 indicated that $60.83 \%$ of the respondents had spent Rs. 50-150 per month, followed by $10.00 \%$ spending $150-200$ per month and only $6.66 \%$ of the respondents above 250 per month, also $22.50 \%$ students had not spent any money on the internet.

Table 3: Respondents According to Their Expenditure on Internet Use (Rupees/Month)

\begin{tabular}{|c|c|c|c|}
\hline S. N & Category & Frequency & Percentage \\
\hline 1. & Nil & 27 & 22.50 \\
\hline 2. & $50-150$ & 73 & 60.83 \\
\hline 3. & $150-250$ & 12 & 10.00 \\
\hline 4. & Above 250 & 8 & 6.66 \\
\hline & Total & $\mathbf{1 2 0}$ & $\mathbf{1 0 0}$ \\
\hline
\end{tabular}




\section{Frequency of Internet Use}

On the basis of table no. 4 we can say most of the respondents has used internet every day out of which $13.04 \%$, $67.39 \%$ and $19.56 \%$ used the internet up to $1 \mathrm{hr}, 2-3 \mathrm{hr}$ and above respectively. It can be also seen that $6.66 \%$ of the respondents used the internet once in a week, $11.66 \%$ respondents used it on occasions.

Table 4: Respondents According to Frequency of Internet Use

\begin{tabular}{|c|c|c|c|c|c|c|c|c|c|}
\hline S. N. & Category & \multicolumn{8}{|c|}{ Time Duration (hours) } \\
\hline & & \multicolumn{2}{|c|}{ Up to 1} & \multicolumn{2}{|c|}{2 to 3} & \multicolumn{2}{|c|}{ Above 3} & \multicolumn{2}{|c|}{ Total } \\
\hline & & $\mathbf{F}$ & $\%$ & $\mathbf{F}$ & $\%$ & $\mathbf{F}$ & $\%$ & $\mathbf{F}$ & $\%$ \\
\hline 1. & Every day & 12 & 13.04 & 62 & 67.39 & 18 & 19.56 & 92 & 76.66 \\
\hline 2. & Once in a week & 1 & 12.50 & 3 & 37.50 & 4 & 50.00 & 8 & 6.66 \\
\hline 3. & Once in a month & 0 & 0 & 2 & 33.33 & 4 & 66.66 & 6 & 5.00 \\
\hline 4. & Occasionally & 9 & 64.28 & 1 & 7.14 & 4 & 28.57 & 14 & 11.66 \\
\hline & Total & & & & & & & 120 & 100 \\
\hline
\end{tabular}

\section{Purpose of Internet Use}

The data presented in the table no.5 revealed that mostly preferred purpose of the internet use were, to collect information $(77.50 \%$ ) and followed by $66.66 \%$ student using the internet for entertainment \& $35.00 \%$ for social communication. Rest of student using the internet for miscellaneous work like blogging, e-teaching etc.

Table 5: Respondents According to Purpose of Internet Use

\begin{tabular}{|c|l|c|c|c|c|c|c|}
\hline S. N. & \multicolumn{1}{|c|}{ Purpose } & Mostly & \% & Sometime & \% & Never & \% \\
\hline 1. & Information gathering & 93 & 77.50 & 19 & 15.83 & 8 & 6.66 \\
\hline 2. & Entertainment & 80 & 66.66 & 17 & 14.16 & 23 & 19.16 \\
\hline 3. & Social communication & 42 & 35.00 & 23 & 19.16 & 55 & 45.83 \\
\hline 4. & Other & 3 & 2.5 & 15 & 12.50 & 102 & 85.00 \\
\hline
\end{tabular}

*Multiple responses were allowed

\section{Exposure of Informative Sites}

The Search engine is used to find out relevant information, respectively $75.00 \% \& 60.00 \%$ student used google scholar \& shodhganga search engine for gathering information and in another hand $85 \%$ used sarkariresult.com for gathering job related information. For study purposes respectively $52.50 \% \& 47.50 \%$ students used sites like agrionline.nic.in, paper out.in \& others.

Table 6: Respondents According to Exposure of Various Informative Websites

\begin{tabular}{|c|l|c|c|c|c|c|c|}
\hline \multirow{2}{*}{ S. N. } & \multirow{2}{*}{ Web sites } & \multicolumn{6}{|c|}{ Frequency of Use } \\
\cline { 3 - 8 } & & \multicolumn{2}{|c|}{ Mostly } & \multicolumn{2}{|c|}{ Sometime } & \multicolumn{2}{c|}{ Never } \\
\cline { 3 - 8 } & & F & \% & F & \% & F & $\%$ \\
\hline 1. & Google scholar & 90 & 75.00 & 18 & 15.00 & 12 & 10.00 \\
\hline 2. & Shodh Ganga & 72 & 60.00 & 26 & 21.66 & 22 & 18.33 \\
\hline 3. & sarkariresult.com & 102 & 85.00 & 18 & 15.00 & - & - \\
\hline 4. & agrionline.nic.in & 63 & 52.50 & 22 & 18.33 & 35 & 29.16 \\
\hline 5. & paperout.in & 57 & 47.50 & 15 & 12.50 & 48 & 40.00 \\
\hline 6. & Other & 44 & 36.66 & 4 & 3.33 & 72 & 60.00 \\
\hline
\end{tabular}

*Multiple responses were allowed 


\section{Devices in Which Mostly Internet Used}

According to our study, we found that students prefer their smartphone for internet access (63.33\%). Respectively $22.50 \% \& 14.16 \%$ used laptop \& desktop for internet access.

Table 7: Respondents According to Preferable Devices for Internet Use

\begin{tabular}{|c|l|c|c|}
\hline S. N. & \multicolumn{1}{|c|}{ Devices } & User & \% \\
\hline 1. & Desktop & 17 & 14.16 \\
\hline 2. & Laptop & 27 & 22.50 \\
\hline 3. & Smartphone & 76 & 63.33 \\
\hline & Total & $\mathbf{1 2 0}$ & $\mathbf{1 0 0}$ \\
\hline
\end{tabular}

\section{CONCLUSIONS}

From the findings of the study, we got that most of the students used the internet for gathering information related to journal, research references, articles and class assignments. Job search also comes in the list because of every student seeking a carrier for the future. For using the internet most of the students prefer night time at the hostel, the reason behind this is network speed which is better at night and regular use of the internet are common now because of the internet on various devices at the cheap rate available now. In the study, we found that most of agriculture students using the internet for the positive purpose like information gathering $\&$ sharing, which can be improved with the help of better equipment in campus because the study has come from paper to the computer.

\section{REFERENCES}

1. Kimra CastletonThomas FongAndrea Wang-GillamMuhammad A. WaqarDonna B. JeffeLisa KehlenbrinkFeng (2011). “A survey of Internet utilization among patients with cancer” Supportive Care in Cancer; 19(8), pp 1183-1190.

2. Md. Salleh Hassan (2009). "Developing Agriculture in Malaysia: Internet Utilization among Malaysian Youth AgroBusinessman” European Journal of Social Sciences: 11(2), p215.

3. Faisal Mustafa, Collection Development in Libraries in Internet Era, International Journal of Library Science and Research (IJLSR), Volume 5, Issue 2, March - April 2015, pp. 45-50

4. Naser Zamani-Miandashti, Payam Memarbashi \& Parvin Khalighzadeh (2014). "The prediction of Internet utilization behavior of undergraduate agricultural students, An application of the theory of planned behavior" International Information \& Library Review: 45(3), pp 114-126.

5. Yousef Homood Aldebasi and Mohamed Issa Ahmed (2013). "Computer and Internet Utilization among the Medical Students in Qassim University Saudi Arabia” journal of clinical diagnostic research; 7(6), pp 1105-1108. 